\title{
A Study on Promoting Inclusive Growth With Reference To Icici Bank
}

\author{
Shephali Mathur \\ Research Scholar Mewar University Chittorgarh, Rajasthan
}

\begin{abstract}
ICICI Bank was incorporated on $5^{\text {th }}$ January and received the certificate for commencement of business on $24^{\text {th }}$ February. Promoting Inclusive growth has been a priority area for the group. They try to make the difference to their customers, to the society and to the nation's development directly through our products and services, as well as through our development initiatives and community outreach. Its main areas of focus for promoting Inclusive growth consists of Primary health, Elementary education, serving communities in partnership with civil society, improving access to financial services and various technology initiatives. These will be achieved through active collaboration with the government and independent organizations.
\end{abstract}

Keywords: Financial Services, Inclusive growth, Technology Innovations

\section{Introduction:}

For over five decades, the ICICI Group has partnered India in its economic growth and development. Promoting inclusive growth has been a priority area for the Group from both a social and business perspective. We strive to make a difference to our customers, to the society and to the nation's development directly through our products and services, as well as through our development initiatives and community outreach.

ICICI Foundation for Inclusive Growth (ICICI Foundation) was founded by the ICICI Group in early 2008 to carry forward and build upon its legacy of promoting inclusive growth. ICICI Foundation works with government authorities and specialised grassroots organisations to support developmental work in identified focus areas. It is committed to investing in long-term efforts to support inclusive growth through effective interventions. The objective of the Foundation is articulated in its Mission Statement:

"To empower the poor to participate in and benefit from the Indian growth process through integrated action in the fields of primary health, elementary education, financial inclusion and sustainable livelihood. This will be achieved through active collaboration with the government and independent organisations."

II. Objective of the Study:

This paper focuses on the initiatives taken by the ICICI Bank for promoting Inclusive Growth. The Bank is taking all necessary steps for the wellbeing of the people and for nation's social and economic development.

For Promoting Inclusive growth the main areas of focus for ICICI Bank are:

1) Primary health: ICICI Foundation works to strengthen public health delivery systems to improve the health of mothers and children in the poorest communities across India in the states of Bihar, Jharkhand, Chattisgarh, Odisha and Maharashtra. It strives to develop solutions to enable the government health systems to become more effective. Some of the key interventions in the field of primary health are:

i. District Health Action Plans: In Bihar, ICICI Foundation has worked with Public Health Resource Network and the National Health Systems Resource Centre to support preparation of District Health Action Plans for the entire state for the third consecutive year. These plans enable proper assessment of the healthcare required and the available resources so that the central government funding can be allocated on an informed basis and focussed actions can be undertaken.

ii. Nutrition Security Programme: This initiative aims to improve nutrition of children aged between six months and three years by enlisting and training the Mitanin (community health workers) to change dietary practices and attitudes in communities. The programme has been undertaken in partnership with the Chhattisgarh State Health Resource Centre in 23 blocks across 11 districts in Chhattisgarh. 9,000 Mitanins were trained in nutrition related issues. The intervention has resulted in improved enrolments in the anganwadis for accessing healthcare and increase in the distribution of food supplements. The household feeding practices have also improved through addition of locally available nurtritious food to the diet.

iii. Maternal Nutrition Project: ICICI Foundation supports the Mumbai Maternal Nutrition Project, a randomised controlled trial on mother and child health. The project is designed to empower women to independently improve their, as well as, their children's nutrition. The project succeeded in achieving its target of enrolling more than a 1,000 pregnant women and documenting nearly 700 births. The study tests the impact 
of enhancing micronutrient quality in women's diets from before conception to delivery, by examining women's health, foetal growth and their children's development.

iv. State Village Health Committee and Sahiyya Resource Centre: Under the National Rural Health Mission (NRHM), Sahiyyas (community health workers) play a key role in linking their communities with public health systems and act as agents for community mobilisation. The Jharkhand State Village Health Committee and Sahiyya Resource Centre was created through an innovative partnership with the Jharkhand state government, central government institutions and civil society organisations. It facilitates the implementation of the Sahiyya and Village Health Committee programmes under the NRHM. The centre has till date trained nearly 41,000 Sahiyyas.

v. Outpatient Health Care Project: ICICI Foundation is partnering with ICICI Lombard General Insurance Company to design, part fund and implement the delivery of India's first outpatient healthcare product for low income households. The project will offer outpatient insurance and will complement the Government of India's national health insurance scheme for inpatient care, the Rashtriya Swasthya Bima Yojana (RSBY). To begin with, this insurance product will be offered through a pilot project in Puri district in Odisha and one district in Gujarat

2) Elementary education: In the field of elementary education, ICICI Foundation seeks to improve the quality of public education by strengthening the state and district-level institutional bodies. Some of the key projects undertaken are:

i. Quality Education Programme: The Quality Education Programme is a collaborative initiative of ICICI Foundation and its partner resource organisations - Digantar, Jaipur and Vidya Bhawan Society, Udaipur - that supports government efforts to improve the quality of elementary education in Rajasthan's Baran district. The major objectives of the project were to strengthen Baran's District Institute of Educational Training (DIET), work with the Sarva Shiksha Abhyan (SSA) team to provide adequate academic support in the district and support selected cluster resource centres to develop model schools. This initiative targeted 125 master trainers, 4,000 teachers from the 1,498 government schools and 144,971 students.

The programme has helped in improvement in the quality of in-service training and classroom teaching practices. The teacher and student attendance has also improved in the schools that were part of the project.

ii. Consultative meeting to improve quality of education: ICICI Foundation organised a consultative meeting to share its work, emerging strategies and long-term plans with various stakeholders at India Habitat Centre, New Delhi. The meeting was attended by the Foundation's long-standing partner organisations, representatives of the Central Government and the State Governments with whom the Foundation works or has plans to work, and independent experts and resource persons. The deliberations helped ICICI Foundation in formulating its proposed state-wide interventions for quality improvement in school education in Rajasthan and Odisha.

iii. State-wide programme for improvements in schools education and teacher training: In Odisha, ICICI Foundation in partnership with the Government of Odisha, plans to launch a programme to improve the practices of in-service (current teachers) and pre-service (trainee teachers) teacher training in the state.

The programme will build the professional capacity of teachers and educators, as well as strengthen the state's teacher performance management mechanism. ICICI Foundation will work with the state education functionaries to facilitate reforms in line with 2005 National Curriculum Framework, including updating curricula, developing teacher training material and designing research and academic support material. The scope of this programme will cover the training of 300 master trainers who will train 4,500 teacher trainers who in turn will train 100,000 in-service teachers and 10,000 pre-service teachers.

In Rajasthan, based on the success of its Quality Education Programme, ICICI Foundation has been invited by the Government of Rajasthan to work with the State Institute of Education Research and Training (SIERT), to revamp the state's teacher training curriculum. The proposed project seeks to revise the pre-service teacher training curriculum, build professional capacity of teacher educators, including the SIERT and DIET faculty and strengthen and improve co-ordination amongst the multi-tier academic support structure. The programme will also develop one block (in one intervention district) as an e-learning hub for supplementing inservice teachers' training and work on development of all schools in two blocks in two districts so that the schools can become compliant with the Right to Education Act. The overall goal is to train 500 master trainers, 80-100 nodal head masters, 20,000 student teachers, 250 key resource persons and 210,000 in-service teachers, which will impact about 8 million students across the state.

c) Access to finance: ICICI Foundation facilitates financial inclusion by supporting the development of new models for delivering financial services viz. credit, savings, remittance and insurance to low-income households. In addition to the ICICI Group's direct work in the area of financial inclusion, ICICI Foundation partners with ICICI Group companies to provide greater access to, and create awareness of finance in communities where it has established health and education programmes.

d) Sustainable livelihoods: ICICI Foundation has broadened the scope of its work to include sustainable livelihoods in order to address the urgent need for adequate training for rural youth. Skill development training 
for the youth, particularly those below the poverty line, is required in order to make them employable or equip them to become entrepreneurs. The Foundation has taken up the mandate to strengthen two Rural SelfEmployment Training Institutes (RSETIs) in Udaipur and Jodhpur engaged in providing training for skill development. The Foundation will focus on providing training that is culturally relevant and locally in demand, and where the input costs are low whereas the returns are relatively high and self-sustaining. It will also facilitate supply chain, credit and marketing linkages, impart basic financial training and provide placement support.

\section{Serving communities in partnership with civil society}

Besides grassroot level interventions undertaken by ICICI Foundation as mentioned above, the ICICI Group companies also undertake certain other projects for the benefit of society, along with ICICI Foundation. These include:

a) Read to Lead - Phase II: In Phase II of the Read to Lead programme, ICICI Bank has supported the establishment of 63 libraries that will reach out to approximately 7,200 children in the rural areas of the Jagdalpur block of Bastar district in Chhattisgarh. The programme includes building libraries, sourcing books and conducting various interactive activities to make the library a dynamic centre for learning.

b) ICICI Fellows: The ICICI Fellows programme, launched in November 2009, aims to create a cadre of socially responsible leaders for India. The two-year programme includes experiential learning in rural or semiurban India, as well as management training and leadership development through personalised coaching and mentorship. The first batch joined in August 2010 and are currently gaining first hand experience through working with the partner NGOs.

c) Healthy Lokshakti: Through this initiative, ICICI Lombard works towards improving the health of mothers and children (0-1 year) in Trimbak and Peint tribal blocks of Maharashtra, in partnership with government healthcare systems. In order to reduce neo-natal and child mortality, it works to ensure that women receive good healthcare during and after their pregnancy and medical assistance during delivery.

d) Muktangan Education Initiative: ICICI Securities supports the Mumbai-based NGO Doorstep School which enriches the schooling experience of 1,265 socio-economically disadvantaged children and supports enrollment and sustenance through activities such as reading promotion, study class, mental health support and extracurricular activities. ICICI Securities also continues to support the Muktangan Education Initiative, a partnership between the Paragon Charitable Trust and the Municipal Corporation of Greater Mumbai. Muktangan seeks to provide affordable, community-based inclusive education to underprivileged children.

e) Payroll giving: Since 2003, ICICI Bank has facilitated employee donations to social causes through GiveIndia. Close to 6,000 employees participate in the payroll-giving programme.

f) Employee volunteering: The "Changemakers" programme enables employees to contribute their time and talent for social change. "ChangeMakers" at one of the teams of ICICI Bank delivered employability and lifeskills sessions to underprivileged youth enrolled in vocational training at Kherwadi Social Welfare Association, an NGO.

g) Blood donation: In order to reduce the blood shortage in India, ICICI Foundation organised a blood donation camp at ICICI Bank Towers in Mumbai together with State Blood Transfusion Council (SBTC), the autonomous regulatory authority for blood banks in Maharashtra set up under the Ministry of Health. The camp received an overwhelming response from the employees and the blood donated went to SBTC's premiere blood bank, Mahanagar Rakthpedhi (MR). MR provides safe blood and its components at the least expensive price in Mumbai. This makes blood more accessible to people from all socio-economic backgrounds. MR also regularly provides blood for free to 150 children with thalesemia and sickle cell disease. SBTC issues everyone a donor card that makes them eligible for one free unit of blood in the state within the next two years. The blood donation drive will now be extended across all offices of the ICICI Group in India.

h) Speak for Smiles: Together with Toofles Foundation and CNBC-TV18, Speak for Smiles, an initiative where young students get an opportunity to interact with business leaders and learn from their experiences was launched. The events are aired on CNBC-TV18 and the proceeds generated by way of contribution from ICICI Foundation are donated to an NGO, nominated by the leaders.

\section{Improving access to financial services}

ICICI Bank has partnered with Unique Identification Authority of India (UIDAI) for a pilot in Hazaribagh, Jharkhand.

Under this pilot, enrollment and opening of Aadhar enabled bank accounts was undertaken and the testing of transactions has been successfully completed. ICICI Bank and ICICI Foundation participated in RBI's outreach programme at Doba village in Jharkhand's Lohardagga district. The outreach programme sought to raise awareness about financial inclusion and banking opportunities available to people in rural areas. ICICI Bank has formulated a financial literacy programme that educates customers on the basics of finance. The Bank conducted finance-themed street plays in Jharkhand and will extend the programme to other parts of the country. 
ICICI Bank has also been chosen by the Bill and Melinda Gates Foundation as one of the five international banks for their "Gateway Financial Innovation for Savings" project to promote useful savings behaviour by poor.

ICICI Prudential Life Insurance Company (ICICI Life) provides micro-insurance to India's lowincome population, as a part of a socially responsible business model. Its micro insurance product for people in rural areas, SarvJana Suraksha, provides insurance for a minimal premium of only ` 50 per annum. ICICI Life has successfully piloted a unique poverty-alleviation project in collaboration with the Micro Insurance Innovation Facility of the International Labour Organization. The project reaches out to the tea workers in Assam. ICICI Prudential Life has also set up and nurtured a Community Video Unit, JAWA at Dimakusi in Assam with Video Volunteer, an NGO. The unit produced videos, conducted several screenings, campaigns and street plays, which educated 2,000 households on preventive measures against malaria, educated 45,000 workers on financial savings and trained 45 tea workers on financial literacy who then conducted ten mass awareness campaigns covering 10,000 workers.

ICICI Lombard General Insurance Company (ICICI General) has partnered with several central and state government ministries/agencies to offer insurance coverage under various schemes of the government.

Under the Rashtriya Swasthya Bima Yojana (RSBY), below poverty line workers in the unorganized sector in Uttar Pradesh, Bihar, Odisha, Gujarat, Maharashtra, Haryana and Punjab have been covered for health insurance. Biometric smart cards issued to each family capture biometric details of the family and the beneficiaries can check the balance sum insured, family details, policy details and coverage at any time during the policy period. ICICI General has also provided a unique health insurance product for weavers and their families. Over 1.6 million families have been covered through this scheme.

A special policy to provide health insurance to women involved in silkworm cultivation and their families is also operational. ICICI General is also working with a number of financial intermediaries to deliver weather insurance solutions for farmers through Weather Based Crop Insurance Scheme (WBCIS). Till date, ICICI General has insured close to 2.8 million hectares of land and 28 crop varieties through the WBCIS product.

\section{Clean technology initiatives}

ICICI Bank's Technology Finance Group (TFG) implements multilateral programmes on behalf of the Government of India in the areas of collaborative research and development, energy, environment and healthcare. TFG's initiatives include efforts to attract and channel private financing into cleaner technologies, to create public private partnerships to mitigate greenhouse gas emissions through energy efficiency and to promote sustainable development.

TFG assisted the introduction of environmental management codes (ISO 14000) in India. It supported clean coal concepts like coal washeries and coal bed methane for the first time in India. TFG supported the development of the first electric passenger car in India, currently being exported to several countries. It also supported the introduction of municipal shared savings concept through the energy service company (ESCO) route, which help save expenditure for street lighting and water pumping. Another significant initiative was the introduction of green ratings for buildings (which helps save energy, water and emissions) through the establishment of Confederation of Indian Industry's Green Business Centre.

In fiscal 2011, TFG in collaboration with leading institutes, has assisted various projects in the areas of solar energy, nuclear energy and drug discovery. This includes assistance to The Energy Resource Institute (TERI) for its project to build capacities of select laboratories for promoting sustainable development in energy efficiency. The laboratories would be equipped with capabilities for developing biomass energy systems, decentralized electricity solutions, waste material characterisation and solar power systems. The laboratories will also promote energy efficiency in the industry through various means including certification of solar lighting products.

\section{Literature Review:}

Although inclusive growth is now well accepted as the key economic goal for developing countries, there are variations in its definition and characterisation (Birdsall, 2007). These are some of the approaches to inclusive growth adopted in the literature:

$\square$ Inclusive growth involves a long term perspective. It focuses on the generation of productive employment, instead of direct income redistribution, in order to increase the incomes of excluded groups. Some redistribution schemes may however be necessary in the short term (Ianchovichina and Lundstrom, 2009).

$\square$ Inclusive growth is 'growth that not only creates new economic opportunities, but also one that ensures equal access to the opportunities created for all segments of society, particularly for the poor' (Ali and Hwa Son, 2007 p. 12).

$\square \quad$ Inclusive growth includes but extends pro-poor growth; it involves 'increasing the size and economic commend of the middle class'. The assumption is that growth which is beneficial for the large majority of 
people in developing countries is more likely to be economically and politically sustainable (Birdsall, 2007).

A large range of policies to promote inclusive growth are discussed in the literature. They include:

$\square$ Enabling environment: government should develop and maintain an enabling environment for business and investment in technology and innovation. Competitive exchange rates can also contribute to inclusive growth through a rise in manufactured exports. Such exports are often associated with investment in new enterprises and creation of jobs for the semi-skilled (Birdsall, 2007). Governments also need to promote an environment for equal participation. Effective legal institutions and rule of law are essential in guaranteeing the rights of people to participate in economic growth (Rauniyar and Kanbur, 2009).

$\square$ Redistributive public expenditures and social protection: inclusive growth can be promoted through progressive tax systems and expenditures - including short-term transfer policies and greater broad-based spending on health, education and public infrastructure (Birdsall, 2007; McKay, 2008; Higgins and Prowse, 2010).

Improvements in access to education and health could facilitate the access and participation of the poor in employment and growth opportunities (Ianchovichina and Lundstrom, 2009). Targeted social protection schemes may also provide poor and vulnerable groups with more economic security, which may allow for greater risktaking (Rauniyar and Kanbur, 2009).

$\square \quad$ Human capital and job creation: support for human capital and the strengthening of capabilities is important for inclusive growth (Rauniyar and Kanbur, 2009). Further, increasing the rate of job creation from growth is necessary to provide opportunities for people to benefit from higher education levels and move out of agriculture (McKay, 2008).

$\square \quad$ Broad-based sectoral growth: since job creation may still not benefit the poorest directly, it is important to adopt a pattern of growth which is broad-based in terms of its coverage of sectors, regions or population. This includes the agricultural sector if its coverage of sectors, regions or population. This includes the agricultural sector if that is the sector in which the poor are disproportionately represented (McKay, 2008). In many countries in Asia, for example, large percentages of the population are rural based and depend on agriculture for a living. Rural infrastructure and agricultural technologies are essential to developing the rural economy and providing rural populations with access to markets, basic services and employment and income opportunities (Rauniyar and Kanbur, 2009).

$\square \quad$ Infrastructure development: quality of infrastructure is an enabling factor that drives inclusive growth (Rauniyar and Kanbur, 2009). Directly targeting business and traderelated infrastructure (e.g. transport, energy and telecommunications) to vulnerable and poor groups can improve their access to and participation in growth. Rural women in many countries, for example, spend significantly more time and income on transport, which reduces their ability to invest in higher value-added activities (Higgins and Prowse, 2010).

$\square \quad$ Partnerships between government and the private sector: there is an increasing number of profit and not-for profit business actors that are drawing on opportunities to serve more of the low-income population and those who live in more remote areas. It is important for government to work with such actors and to provide support for businesses to expand services to the poor the vulnerable (Mendoza and Thelen, 2008; Rauniyar and Kanbur, 2009; Chakrabarty 2009).

$\square \quad$ Assessment and monitoring: it is essential to assess the constraints to sustained high growth for all groups in society and to determine how different segments of society are affected. Support must be given to governments such that they can collect disaggregated data and adopt an inclusive approach (Higgins and Prowse, 2010; Ianchovichina and Lundstrom, 2009). It is also essential to design ways in which to measure inclusive growth and the extent and degree to which inclusiveness is attained (Ali, 2007; Higgins and Prowse, 2010).

\section{i) Type of Research:}

\section{Research Methodology:}

In this paper Exploratory research and Descriptive research design are used in this type of research.

Exploratory research is a type of research conducted for a problem that has not been clearly defined. Exploratory research helps determine the best research design, data collection method and selection of subjects. It should draw definitive conclusions only with extreme caution. Given its fundamental nature, exploratory research often concludes that a perceived problem does not actually exist.

Descriptive research includes surveys and fact-finding enquiries of different kinds. The major purpose of descriptive research is description of the state of affairs as it exists at present. 
ii) Collection of Data:

Secondary source: It includes published data and the data collected in the past or other parties. Information has been sourced from books, research papers, journals, magazines and websites. In this paper the data has been collected from ICICI Bank's Annual Reports.

\section{Analysis:}

The analysis says that the programmes and steps taken by the ICICI Bank for promoting Inclusive Growth will definitely benefit the society and especially to the poor people in their health prospects, education and many others.

\section{Conclusion:}

For over five decades, the ICICI Bank is contributing its best for the economic growth and development of the country. Promoting Inclusive Growth has been a priority area for the group from both social and business perspective and it is keep on working for the nation's development through its various products and services as well as through development initiatives and community outreach.

\section{Books-}

\section{Bibliography:}

[1]. Beri - Marketing Research (Tata McGraw Hill, 4th Ed.)

[2]. Bhole L M - Financial Institutions and Markets (Tata McGraw-Hill, 3rd edition, 2003)

\section{Websites-}

1) www.icici.com

2) www.research \& markets.com

3) www.scribd.com

4) www.business-standard.com/special/bankannual/2003/tech.htm

5) www.banknetindia.com/banking/bsoftware.htm

6) www.iloveindia.com/finance/bank/nationalised-banks/index.html

7) www.en.wikipedia.org/wiki/Private_bank

8) www.en.wikipedia.org/wiki/Bank 